\title{
The Enrichment of the Vocabulary through Word Formation Processes in both English and Albanian Languages
}

\author{
Olsa Xhina \\ "Aleksander Moisiu" University of Durres, Albania \\ E-mail: olsa.xhina@gmail.com
}

\section{Doi:10.5901/ajis.2012.v2n4p273}

\begin{abstract}
:
During the process of English language acquisition as a foreign language, as well as in countless translations, the Albanian speaker both as a learner and a user of English language firstly faces with its semantic and lexical structure. The lexical structures of both languages have their pecularities, which appear among others, even in the different volume of lexical, semantic and idiomatic wealth. The creation of new words, the immediate nominating response to multifaceted developments of material, spiritual, intellectual and aesthetic world, makes English the language with the most powerful status today. This paper aims at studying some of the essential means of vocabulary enrichment in both English and Albanian language, in terms of syntactic means, by comparing and contrasting. The study will cover the potential to create new words in both languages, such as derivation, compounding, conversion as well as borrowings in English and Albanian.
\end{abstract}

Key words: vocabulary enrichment, syntactic means, derivation, compounding, conversion, borrowings.

\section{Introduction}

A characteristic of all human languages is the potential to create new words. Throughout the history of the English and Albanian languages new words have been incorporated into the language trough borrowings as well as through the application of morphological and derivational rules to existing words and morphemes.

This paper aims at studying the potential to create new words through wordformation processes in both English and Albanian languages. Interest in wordformation processes is probably as old as interest in language itself. Many of the questions that scholars are asking now were also being asked in the seventeenth, eighteenth and nineteenth centuries. (Bauer, 1983)

The two most common types of wordformation in English and Albanian languages are derivation and compounding, both of which create new words from already existing morphemes. Derivation is the process by which a new word is created through the addition of affixes. On the other hand, compounding is a process involving the combination of two or more roots to give a new word. Other types of word formation are conversion, clipping, blends, backformation.

\section{Characteristics of wordformation in English}

How are new words being formed in the English language? The process consists of a combination of morphemes that are rule-governed (a new word is formed).

\section{Compounding}

Compounding is the combination of two or more roots. In English the roots which are combined to form compounds are usually nouns, adjectives, verbs or prepositions. The most common type of word formation is the combination of two (or more) nouns in order to form a resulting noun: $\mathrm{N}+\mathrm{N}=\mathrm{N}$ (noun), for eg. landmine, wallpaper, toothbrush. The first of the two compounds may be descriptive (i.e. tablecloth, a cloth with which to 
clean [or cloth] tables), or both compounds may create a whole new meaning altogether (i.e railroad, which is not a "road" in the typical sense of the word.) It is also possible to form words whose components are equally important to or descriptive of its meaning, for example, a washer-dryer refers to an object combining two functions.

\section{Types of compounds}

Compounds are sometimes written as a single word, sometimes with a hyphen, and sometimes as separate words. From this classification derive the three types of compounding: solid compound, temporary compound and open compound.(Shqerra,2009)

- Solid compounds or compounds written as one word are the most common type of compounds. Also called as "closed" forms in which two usually moderately short words appear together as one. Examples are housewife, lawsuit, wallpaper, basketball, Combinations of words in solid compounds are:

Adjectives plus nouns (blackboard)

Noun plus adjective (goldfish)

With an adverb in initial position (background)

Adverb plus verb (overcome, outline)

Noun plus noun (handwriting)

- Temporary compounds have the hyphenated form in which two or more words are connected by a hyphen. Compounds that contain affixes, such as house-build(er) and single-mind(ed)(ness), as well as adjective-adjective compounds and verb-verb compounds, such as blue-green and freezedried, are often hyphenated. Compounds that contain articles, prepositions or conjunctions, such as rent-a-cop, mother-of-pearl and salt-and-pepper, are also often hyphenated.

- Open compounds consist of two or more words written separately. According to the linguist Turn Richard in his "A comprehensible grammar"(England, 2000), a typical feature of English compounds is that many of them are unstable. Even the same author may use some lexical group as word group in one place and as compounds in another place. Scientific compounds are usually not hyphenated and are open compounds: eg.: carbon monoslide poison, dichromic acid solution. A classifying genitive plus a noun is also an open compound for eg.: A child's play, a bird's nest). Adjective plus noun (public school, young man) are open compounds.

\section{Derivation}

It is the process of creating new words by adding prefixes and suffixes to the root of the existing word. It is one of the most important types of wordformation in all languages. Derivation can be by adding a prefix to the root (rewrite) or a suffix (talker), as well as adding a prefix and a suffix at the same time (unhappiness) By means of derivation there are created new words by changing the grammatical category of the word to which it applies. There should be distinguished both types of affixes, the inflectional affixes and the derivational affixes. The inflectional affixes, which are only eight of them, merely modify a word ( table-tables, birdbird's, stay- stays- stayed -staying), whereas derivational affixes create a new word of an other grammatical category for eg.: happy -happiness; taste -tasty; real -realize.

\section{Prefixes}

Prefixes in English language do not usually change the grammatical category of the root word. In his book "The word-formation in English"(2003), Plag classifies the prefixes of English semantically into the following groups. First, there is a large group that quantify over their base words meaning, for example, 'one' (uni-, unilateral, unification), 'twice or two' (bi-, bilateral, bifurcation and di-, disyllabic, ditransitive), 'many' (multi-, 
multi-purpose, multi-lateral and poly-, polysyllabic, 'half' (semi-, semi-conscious, semi-desert), 'all' (omni-, omnipotent,omnipresent), 'small' (micro-, micro-surgical, microwave), 'large' (macro-, macroeconomics, macro-biotic), 'to excess' (hyper-, hyperactive, hypermarket and over-, overestimate, overtax), 'not sufficiently' (undernourish, underpay).

Second, there are numerous locative prefixes such as circum- 'around' (circumnavigate, circumscribe), counter- 'against' (counterbalance, counterexample), endo-'internal to X' (endocentric, endocrinology), epi'on, over' (epiglottis, epicentral), inter-'between' (interbreed, intergalactic), intra- 'inside' (intramuscular, intravenous), para-'along with' (paramedic, paranormal), retro- 'back, backwards' (retroflex, retrospection), trans- 'across' (transcontinental, transmigrate). Third, there are temporal prefixes expressing notions like 'before' (ante-, preand fore-, as in antechamber, antedate, preconcert, predetermine, premedical, forefather, foresee), 'after' (post-, poststructuralism, postmodify, postmodern), or 'new' (neo-, neoclassical, Neo-Latin). A fourth group consists of prefixes expressing negation (a(n)-, de-, dis-, in-, non-, un-). (Plag, 2003).

Below are examples of the types of prefixes in the English language:

\section{Prefixes of attitude}

There are several prefixes of this type, such as: pro, anti, contra, co.

Pro: pro-choice, pro-life, pro-market, pro-libertarian. It is usually added to nouns, adjectives of denomination. Anti: anti-missile, anti-social, antibody, anti-abortion, anti-regulatory; = antagonistic:anti-hero, antichrist. This prefix is added to nouns, adverbs, denominal adjectives.

Counter: to counteract, counter-revolution, counter-example, counter-espionage, counter-productive; added to: verbs, abstract nouns, adjectives.

Contra: contraception, contraindicate, contradistinction; added to: abstract nouns, verbs.

Co: cooperate, co-pilot, co-author, cooperation; added to: nouns, verbs.

\section{Reservative and deprivative Prefixes}

These prefixes describe actions being reversed or of antonymic character. Here are some examples of them: un, de, dis.

Un: to untie, to unpack, to unhorse, to unscramble, to unlock. It is usually added to verbs.

De: to decriminalize, to deselect, to decontaminate, to debug, to defrost, to delouse, to deplane, to detrain, to decamp, deforestation; It is added to verbs, abstract nouns.

Dis: to disqualify, to disinvite, to disenfranchise, to disarm, to disillusion, to disambiguate, discoloured, disconnected, discontent, dissatisfaction; It is added to verbs, participles, nouns.

\section{Negative Prefixes}

A: atheist, amoral, asymmetry, apolitical, asexual; It is added to adjectives and nouns.

Dis: disloyal, distrust, disagree, dislike, disfavour, disadvantage; added to: adjectives, abstract nouns, verbs. Un: in-, il-(before I), im-(before p), ir-(before r); unfair, unassuming, unexpected, unproductive, insane, injustice, intolerance, impatience, imperfect, irregular, illegal, incapable, illogical, improper, irrelevant. These are added to: adjectives, participles (only un-).

Non: non-stop, non-interference, non-aggression, non-smoker, non-drip (paint), non-person, non-event; This prefix is added to various types of words and expressions, mainly nouns and verbs.

\section{Pejorative prefixes}

Mis: mismanagement, to miscalculate, to misgovern, to mishandle, misleading, misconduct, to misinform (inform wrongly; whereas disinformation means the deliberate spreading of false or distorted 
information); It is added to verbs, abstract and participles.

Mal has the menaning of bad(ly), improper(ly): malpractice, malinformation, malnutrition, maltreatment, to malfunction, maladjusted, malformed, malodorous; It is added to verbs, abstract nouns, participles, adjectives, but only words of latin origin.

Pseudo: pseudo-education, pseudo-intellectual, pseudo-science, pseudo-Gothic; It is added to nouns and adjectives.

Crypto: crypto-fascist, crypto-Catholic, cryptography; it is added to nouns.

\section{Locative prefixes}

Locative prefixes determine the place, or relative place, or (relative) direction, of action or objects. Also, abstract nouns and processes or relations are determined in terms of locality:

Ante: antechamber, anteroom; It is added to: nouns.

Circum: circumnavigate, circumlocution, circumcision; It is added to: verbs and nouns.

Extra: extramarital, extracurricular, extrasensory, extra-pay; It is added to: adjectives and nouns; Fore = in front, front part of: forefinger, foreskin, forecourt, forehead. It is added to nouns.

In: also il-, im-, ir- ingathering, indoors, in-patient (not impatient); added to: participles, nouns.

Inter: interracial, international, interdisciplinary; added to: adjectives and nouns.

Intra: intramural, intra-uterine, intravenous; It is added to adjectives.

Mid: midfield, mid-point, midway; added to: nouns.

Out: outdoor, out-patient, outlook; added to: nouns; = to surpass: to outrun, to outnumber, to outgrow, to outdistance, to outbid; added to: verbs.

Over: to overthrow, to overshadow, overcoat; added to: verbs, nouns; = excessive: overemphasis, overanxious, to overcharge, to overfish; added to: nouns, verbs.

Retro: to retroflex, to retrorocket, to retroject; added to: verbs.

Sub: subway, subsoil, subconcious; added to: nouns, adjectives; = secondary, lesser in rank: sub-editor, subdean, subleader, sub-climax; added to: nouns; = subordinate part of: subcommittee, sub-plot, sublet, subtitle; added to: nouns; = below the norm: subhuman, subzero, substandard; added to: adjectives, nouns. = to exchange: to substitute; added to: verbs.

Super: superstructure, superimpose, superterrestrial; added to: nouns, verbs, adjectives; beyond the norm:superhuman, superman, supergun, superstar; added to: nouns, adjectives; excessive, excessively: superconformity, superconfidence, supersensitive, superabundant, supercritical; added to: nouns, adjectives.

Supra: supranational, supramundane; added to: adjectives.

Sur: surtax, surcharge, surtitle; nouns, verbs.

Tele: telecommunication, television; added to: nouns, verbs.

Trans: transatlantic, transnational, transsexual; added to: adjectives, geographical names.

Ultra: ultra-violet, ultra-sonic, ultra-modest, ultra-thin, ultra-modern, ultra-orthodox; added to: adjectives. (http://peisker.de/wordformation.htm)

Under: underground, undercarriage, underclothes; added to: nouns; = too little; undercharge, underpay, undercook, undervalue: added to: verbs; = subordinate: under-secretary, underclass.

\section{Prefixes of Size, Degree and Status}

These prefixes determine mostly nouns, and are self-explanatory to a large extent: arch: archbishop, arch-rival, archangel, archduke, arch-enemy; added to: nouns. macro: macrocosm, macro-economics; added to: nouns. micro: microtransmitter, micro-computer, microsurgery, micro-economics; added to: nouns. mega: megastar, megastore; added to: nouns. 
mini: miniseries, minibreak, minicab, miniskirt; added to: nouns.

over/under: to overcook, to underheat; added to: any verb of action.

hyper: hypercritical; added to: adjectives.

co: co-founder, co-presenter; added to: nouns, verbs.

pro: procounsul, pro-vice-chancellor; added to: nouns of latin origin.

vice: vice president.

\section{Prefixes of Time and Order}

Ante: antenatal, antedate.

Ex: former: ex-wife, ex-president; human nouns.

Fore: before: to foresee, to foretell, foregone..

Mid: middle: mid-afternoon, midwinter, midnight.

Neo: new, recent form of, revived: neo-colonialism, neo-conservative, neo-fascist.

Post: after: post-war, post-modernism, post-structuralist.

Pre: before, pre-arranged before the time/period of: prepay, pre-existing, predate, preview, preschool, pre-war, pre-marital.

Re: again, back: reprint, reapply, renew, re-evaluate, resettlement.

\section{Suffixes}

On his book "Word-formation in English" (2003), Plag studies different types of suffixes: verbal suffixes, nominal suffixes, adjectival suffixes, adverbial suffixes:

\section{Verbal Suffixes}

There are four suffixes which derive from other categories, mostly adjectives and nouns:

(-ify, -ize, -ate, -en). to frenchify.

-ify= to make, to cause: to simplify, to beautify, to classify, to personify, to countrify, to ladify, to prettify,

-ize = also -ise = to make, to treat in the way of: to scandalize, to civilize, to organize, to circularize, to mesmerize, to americanize, to familiarize, to legalize, to nationalize, to soberize, to patronize, to materialize, to popularize, to prioritize, to privatize.

-en = to make, to make become: to strengthen, to blacken, to darken, to deepen, to harden, to shorten, to widen, to deafen, to sadden.

-ate = to add or provide with: to chlorinate, to dehydrate, to urinate, to ventilate; added to: nouns in order to form both transitive and intransitive verbs meaning: "to add to something whatever is expressed by the original noun"; or, "to perform or carry out actions obviously meant by the original noun".

\section{Nominal suffixes}

According to Glag (2003), nominal suffixes are often employed to derive abstract nouns from verbs, adjectives and nouns. Such abstract nouns can denote actions, results of actions, or other related concepts, but also properties, qualities and the like.

-ant (as well as -ent) = who / that carries out, agentive and instrumental: informant, claimant, solvent, inhabitant, disinfectant, servant.

-er = also -or in words of latin origin: server, dreamer, cleaner, recorder.

-ing = agentive: the working (a definite article is mandatory); added to: verbs; = activity: swimming, gardening, manufacturing; added to: verbs; = result: building, clothing, painting. 
-ee = passive, affected by: employee, interviewee, teachee, trustee, evacuee; added to: verbs. The resulting noun must denote a person.

-ed = passive, affected by: the unemployed.

-eer $=$ denoting the person carrying out a certain action: auctioneer, sloganeer, volunteer .

-ery $=$ also - ry = brewery, bakery .

-ist: communist, fascist, royalist; converted from: abstract nouns ending -ism or added to certain adjectives (royal); Also it has the meaning (a person practising science or art, trade or profession: archaeologist, violinist, tobacconist, dentist.

\section{Adjectival Suffixes}

The adjectival suffixes of English can be subdivided into two major groups: relational adjectives, for example, algebraic mind means 'a mind having to do with algebra, referring to algebra, characterized by algebra', colonial officer means 'officer having to do with the colonies', and so on; and qualitative adjectives which express more specific concepts (Plag 2003). Here are some types adjectival suffixes:

-able (also -ible on words of Latin or French origin) breakable, eatable, exchangeable, pitiable, readable, reliable, available, objectionable, treasonable, knowledgeable, agreeable, forgettable, unthinkable, intelligible, responsible, audible etc. (Plag, 2003).

-al (also -ial) - meaning "of the nature of", "belonging to": natural, occasional, educational, coastal, tidal, accidental, managerial, musical, criminal, editorial, provisional, continental; added to: nouns in order to form primarily non-comparable adjectives.

-an (also -ian) - meaning "in the tradition of", "coming from", "of the nature of": African, Indian, Elizabethan, Victorian, republican.

-ed - booted, spurred, cultured, landed, moneyed, talented, wooded, earthed, fashioned, one- eyed, balconied.

-en = being made or composed of (Materials): wooden, woollen, leaden, earthen; added to: nouns denoting materials.

-ese = coming from, being of the nature of; Chinese, Milanese, Portuguese; added to: Some geographic names of foreign nature.

-esque $=$ after the manner of (artists especially): Rembrandtesque, picturesque (methaphorical, picturelike); added to: Proper names, nouns denoting stylistic or art-like devices (a picturesque language).

-fold = so many times: twofold, tenfold, manyfold; added to: numerals higher than one; "many".

-ful = being full of, having the nature of, giving: cheerful, doubtful, powerful, careful, resentful, mindful, useful, helpful, spoonful; added to: chiefly abstract nouns.

-ic = of the nature of: energetic, emphatic, systematic, comic, domestic, laconic, phonetic, tragic, Arabic, aristocratic, dramatic, Napoleonic; added to: nouns, proper names.

-ical = of the nature of: biological, economical, comical, historical.

-ing = something experienced like ... (verbs); amazing, amusing, dazzling, trifling, shocking.

-ish = of the nature of: Swedish, feverish, youngish, childish, sevenish added to: geographical names, adjectives, nouns, numerals denoting time or age (fivish = around five; thirtyish = about 30 years of age).

-less = devoid of: careless, harmless, restless, borderless, merciless.

-like $=$ of the nature of, behaving like: childlike, gentlemanlike, godlike.

$-\mathrm{ly}=$ of the nature of, periodic recurrence: cowardly, kingly, earthly, monthly, daily.

-some = productive of: burdensome, fearsome, quarrelsome, troublesome, tiresome, lonesome.

-ward = in the direction of: upward, eastward, onward, heavenward, homeward, landward, backward, forward (as from fore).

$-y=$ of the nature of: funny, rusty, smelly, sleepy, choosy, bony, nervy, headachy, second-classy, catchy, sticky fishy, flimsy (derobitary: fishy character). 


\section{Conversion}

It is the creation of a new word without altering the shape of existing word by affixation. Conversion changes the grammatical category of the word. There are five types of conversion. (Shqerra, 2009)

1. Verbs derived from nouns (nurse, cash, ship, mail)

2. Nouns derived from verbs (dance, love, doubt, turn, laugh)

3. Verbs derived from adjectives (open, calm, empty, clean, dirty)

4. Noun derived from adjectives (the rich, the young, the poor)

5. Verbs derived from prepositions (to down a beer. To out sb)

Other types of wordformation in English are: clipping, backformation, blends, acronyms, and onomatopoeia, but these are surely not as productive as the other types mentioned above.

\section{Backformation}

It is a process in which a new word is created by shortening the existing word. For eg.: abled (disabled), to explete (expletive), to enthuse (enthusiasm), to liase (liason); to burgle (burglary), to edit (edition, editor), to peddle (peddler), to scavange (scavanger).

\section{Blends}

Blends are words created by connecting parts of two words, for example brunch (from breakfast and lunch), smog (from smoke and fog).

\section{Characteristics of wordformation in Albanian}

In Albanian wordformation the two most important types of wordformation are derivation and compounding. Derivation is the most productive type of creating new words even in Albanian language.

There are four types of wordformation by means of derivation process in Albanian language; by means of prefixes, suffixes, prefixes and suffixes simultaneously and without affixes. (Celiku, Karapinjalli 2007)

Words created by means of prefixes mean adding a prefix to the existing root. This type of wordformation is less productive than the one by adding a suffix.

\section{Prefixes}

Aleksander Xhuvani has accounted 68 prefixes in his book "Prefixes of Albanian language", but many of these are not in use today (n-, m-, s-, a-) (Shqerra 2009).

According to the grammar book of the Albanian Academy of Science,"Gramatika e gjuhës shqipe"(2002), prefixes do not usually change the grammatical category in Albanian wordformation. Thus, a prefix is added to a verb to create an other verb, or added to a noun ro create an other noun, added to an adjective to form an other adjective etc. (Celiku, Karapinjalli 2007). It merely gives an other meaning to the new word of the same grammatical category which is created.

Combination types of prefixes with roots are:

Prefix + a verb= verb eg.: Vlerësoj - zhvlerësoj;

Prefix + a noun =noun :afërsi - përafërsi;

Prefix + an adjective $=$ adjective eg. $:$ i lidhur - i ndërlidhur

Prefix + an adverb = adverb gjithmonë - përgjithmonë.

The most used prefixes are: për, mbi, nën, ndër, pa, jo, mos, sh, zh, stër, ç, ri, shpër, gjithë, pas, jashtë, sipër, vetë, gjysme, shumë.

Për is added to verbs, to nouns, adjetives, adverbs. Examples.: (forcoj - përforcoj), (masë - përmasë). 
Mbi is added to nouns, adjectives, verbs. Examples: (shkrim-mbishkrim), (njerezor-mbinjerezor), (zotëroj-mbizotëroj).

Nën is added to nouns, adjectives, verbs. Examples: (oficer-nënoficer), (tokesor-nentokesor), (qeshnenqesh), etc.

Ndër is added to verbs, adjectives, nouns.(hyj-ndërhyj); (kombëtar-ndërkombëtar); (veprim ndërveprim).

$\mathrm{Pa}$ is added to adjectives, participles to create adjectives with a negative meaning, antonyms, nouns: (i ditur - i paditur); ( i shkruar - i pashkruar); barazi - pabarazi.

Jo- is added to adjectives, verbal nouns: (demokratik - jodemokratik), (besim - mosbesim).

Sh-/zh-/ç- are added to verbs to create verbs with negative meanings, adjectives: (thur- shthur); (genjejzhgenjej); (armatos-çarmatos).

S-/z-: kuq-skuq; mbuloj-zbuloj.

$\mathrm{Ri}$ is added to verbs: punoj - ripunoj.

Stër- is added to nouns, adjectives and verbs, for eg: (lodhje-sterlodhje), (i gjate- i stergjate); (hollojsterholloj) etc. (Celiku, Karapinjalli 2007)

Foreign prefixes or borrowed prefixes in Albanian language are: a, anti, de, dez, dis, pro, pan, trans, ultra, poli, super, auto, inter etc. In some cases the words created with such borrowed prefixes are completely replaced by Albanian prefixes. (Celiku, Karapinjalli 2007) (normal-anormal; jonormal); (fetar-afetar; jofetar).

\section{Suffixes}

In Albanian wordformation the suffixation process is the most productive type in creating new words. (Albanian Academy of Science, Morphology, 1976) Albanian suffixes are three times more than prefixes and their meanings are a lot more varied than prefix meanings in creating new words. By means of suffixes there are created nouns, adjectives, verbs, adverbs. Suffixes in Albanian wordformation apart from giving a new meaning to the new word created, they also have a classifying function. They also determine the part of speech of the new word.

-or, - tor, - tar, -os, .(vul-os, hark-ëtar, afr-o-j)

Foreign suffixes or borrowed suffixes in Albanian language are: ist, ier, er, ant, ent, xhi, çi.

Examples: central - centralist, banke - bankier, kurs - kursant, asistoj - asistent, boje -bojaxhi; sahat sahatçi. (Celiku, Karapinjalli 2007)

\section{Prefix Root Suffix}

Apart from the formations with prefixes and suffixes, in Albanian there is an other type of wordformation, in which words are formed by adding a prefix and suffix simultaneously as perfundoj, perkrenare, perfagesoj, shfrytezoj, zhdoganoj etc. This type is the least productive of all the other derivational types of wordformation process.

\section{Words formed without an affix}

We provide the examples of nouns derived by verbs, eg.: hap-i, (step), mund-i (effort), or verbs shendosh(get fat) formed by the adjective shëndoshë.

\section{Compounding}

In Albanian language and morphology the process of compounding consists of these categories or groups: compounded words, attached words (fjalet e perngjitura). 
Attached words make the most interesting type which does not exist in English wordformation process. They are words created historically with the passing of time as used always together. They differ from the compound words due to the fact that they cannot be divided in two words, as compound words do. Attached words in Albanian are: gjëegjëzë (puzzle), farefis (kinship), askush (nobody) etc.

\section{Conversion}

This type of wordformation is also found in Albanian language; the creation of prepositions out of adverbs: afer, anes, brenda, drejt, gjate, jashte etc; the creation of nouns out of adjectives eg.: e bukura, te lashtat, te ardhurat, i ri, i ditur etc (Albanian Academy of Science, Morphology, 1976).

Another typical type of wordformation in Albanian is by adding the former artcle to the existing word. In Albanian this typical wordformation type is called paranyjëzim. It is a very productive way of creating words, but not found in English language. The rule is that most of the participles can turn into adjectives by adding the former article and there is created a new word, which belongs to an other part of speech.

Eg.: hapur - i hapur(adj) (open), lagur - i lagur(adj) (wet), qeshur - i qeshur (adj) etc.

\section{Conclusions}

This study aimed to give an overview of the main types of the wordformation types in both English and Albanian language consulting different sources of information, mostly grammars and articles by foreign and Albanian linguists. The focus of this paper was the study of the vocabulary enrichment by means of wordformation processes, the ones which result as the most productive in creating new words.

In the derivational process, in both languages, there are used prefixes and suffixes to create new words. Acronyms exist in all languages and all have onomatopoetic words.

However, we noticed some specific characteristics of the Albanian language which do not exist in English. So, in Albanian derivation there are words created by means of the use of a prefix and suffix simultaneoulsy as: përfundoj, shfrytëzoj, përkrenare etc. English wordformation process does not typically apply this rule.

Secondly, words formed by adding the former article, in Albanian is called paranyjezim. This characteristic does not exist in the English language as it doesn't have former articles.

Thirdly, attached words which have an historical formation, are still typical of the Albanian wordformation. We do not find this characteristic in English language.

However, blends, backformation and clipping are more typical of English language. Even though we can find several examples of blends, backformation and clipping in the Albanian language, still they are quite limited in number, if compared to the English language.

In conclusion, both languages do have the potential to create new words by means of the wordformation process, by which a wide range of new words are formed in English and Albanian languages. We should also mention here the great contribution of English language as a world language in the enrichment of the Albanian language through borrowings. Albanian language has strongly been influenced by the English words in many aspects of life.

\section{References}

Akademia e Shkencave te Shqiperise, 1976, Tirane, "Fonetika dhe gramatika e gjuhes se sotme letrare shqipe". Akademia e Shkencave, 2002, Tirane "Gramatika e gjuhes shqipe", 1. Morfologjia.

Celiku M, Karapinjalli M, Stringa R, 2007, Tirane "Gramatika praktike e gjuhes shqipe" Toena.

Turn Richard, England 2000, "A comprehensible grammar".

Shqerra, E. "C.A of wordformation in English and Albanian languages".2009.

Thomai Jani, 2006, Tirane, "Leksikologjia e gjuhes shqipe". 
Bauer, L.(1983), "English word-formation". Cambridge University Press

Plag, I.(2003),"Word-formation in English".

http://www.translationdirectory.com/article37.htm 